\title{
KLASIFIKASI KELAYAKAN PINJAMAN PADA KOPERASI KARYAWAN MENGGUNAKAN METODE NAÏVE BAYES CLASSIFIER BERBASIS WEB
}

\author{
Iwan Riswanto ${ }^{1}$, Riffa Haviani Laluma ${ }^{2}$ \\ ${ }^{1,2}$ Program Studi Teknik Informatika, Universitas Sangga Buana \\ riswan0584@gmail.com¹, rhaviani@gmail.com²
}

\begin{abstract}
ABSTRAK
Koperasi karyawan adalah lembaga yang berada di bawah perusahaan yang semua anggota dan staf nya adalah karyawan perusahaan itu sendiri. CV. Rabbani Asysa adalah salah satu perusahaan yang memiliki koperasi bernama Kokerasa yang merupakan kependekan dari Koperasi Kesejahteraan Karyawan Rabbani Asysa. Pengelolaan data pengajuan pinjaman di Koperasi Kokerasa masih menggunakan sistem konvensional yang menggunakan Microsoft Excel, metode ini dianggap tidak efektif karena menimbulkan banyaknya antrian pengajuan pinjaman yang belum diproses. Oleh karena itu diperlukan aplikasi untuk menentukan kelayakan pinjaman menggunakan metode Nä̈ve Bayes Classifier (NBC), yang merupakan metode klasifikasi menggunakan probabilitas dan statistik yang dikemukakan oleh ilmuwan Inggris Thomas Bayes. Algoritma Naive Bayes memprediksi peluang masa depan berdasarkan pengalaman sebelumnya.
\end{abstract}

Kata Kunci: Koperasi, Klasifikasi Pinjaman, Pengolahan Data, Nä̈ve Bayes.

\section{PENDAHULUAN}

Penggunaan teknologi informasi dalam sebuah instansi saat ini sangat penting karena dapat memudahkan sebuah instansi untuk mengolah data menjadi sebuah informasi yang bermanfaat bagi pengguna nya. Untuk dapat menggunakan teknologi informasi tersebut dibutuhkan lah sebuah aplikasi, yaitu suatu unit perangkat lunak yang dibuat untuk melayani kebutuhan akan beberapa aktivitas (Buyens, 2001).

Koperasi karyawan merupakan sebuah instansi yang berada dibawah perusahaan yang semua anggota dan pengurus nya adalah karyawan di perusahaan itu sendiri. Salah satu fasilitas yang disediakan oleh koperasi ini adalah jasa pinjaman, yang selalu dibutuhkan oleh para anggota nya, karena anggota koperasi dapat meminjam sejumlah uang dengan cicilan dan margin yang ringan.

Dengan jumlah anggota 1450 orang pada awal tahun 2019, pengelolaan data pada Koperasi Karyawan Rabbani Asysa ini masih menggunakan sistem konvensional yaitu menggunakan Microsoft Excel, dengan bertambah nya anggota yang ada di koperasi, cara ini dinilai kurang efektif karena pengajuan pinjaman semakin banyak. Dalam menentukan pengajuan pinjaman yang layak, pengurus koperasi karyawan rabbani masih menggunakan cara manual, yaitu hanya mengecek kelayakan parameter dari setiap tanpa melakukan perhitungan dari setiap atribut tersebut.

Penentuan klasifikasi kelayakan pinjaman yang digunakan adalah metode Naïve Bayes Classifier (NBC).

\section{TINJAUAN PUSTAKA}

\subsection{Pengertian koperasi}

Koperasi adalah suatu badan usaha (organisasi ekonomi) yang dimiliki dan dioperasikan oleh para anggotanya untuk memenuhi kepentingan bersama di bidang ekonomi. Koperasi dapat didirikan secara perorangan atau badan hukum koperasi. Badan usaha ini mengumpulkan dana dari para anggotanya sebagai modal dalam menjalankan usaha sesuai aspirasi dan kebutuhan bersama di bidang ekonomi.

Koperasi simpan pinjam karyawan adalah suatu koperasi dibawah sebuah perusahaan yang kegiatan usahanya menghimpun dan menyalurkan dana kepada para anggotanya dengan margin yang rendah. Koperasi ini 
disebut juga sebagai koperasi kredit karyawan dimana pengelolaannya dilakukan secara mandiri dan demokratis, serta para anggotanya adalah para karyawan itu sendiri yaitu merupakan sebuah metode klasifikasi menggunakan metode probabilitas dan statistik yg dikemukakan oleh ilmuwan Inggris Thomas Bayes. Algoritma Naive Bayes memprediksi peluang di masa depan berdasarkan pengalaman di masa sebelumnya. Kelebihan menggunakan metode ini hanya membutuhkan jumlah data pelatihan (training data) yang kecil untuk menentukan estimasi parameter yg diperlukan dalam proses pengambilan keputusan.

Untuk mengatasi masalah peminjaman koperasi tersebut maka dibuatlah penelitian dengan judul "Klasifikasi kelayakan pinjaman pada koperasi karyawan menggunakan metode naïve bayes classifier berbasis web"

\subsection{Data Mining}

Data mining adalah suatu istilah yang digunakan untuk menguraikan penemuan pengetahuan di dalam database. Data mining adalah proses yang menggunakan teknik statistik, matematika, kecerdasan buatan dan machine learning untuk mengektraksi dan mengidentifikasi informasi yang bermanfaat dan pengetahuan yang terakit dari berbagai database besar (Turban, dkk.2005)

\subsection{Tahapan Data Mining}

Tahapan yang dilakukan pada proses data mining diawali dari seleksi data dari data sumber ke data target, tahap preprocessing untuk memperbaiki kualitas data, transformasi, data mining serta tahap interpretasi dan evaluasi yang menghasilkan output berupa pengetahuan baru yang diharapkan memberikan kontribusi yang lebih baik. Secara detail dijelaskan sebagai berikut (Fayyad, 1996).

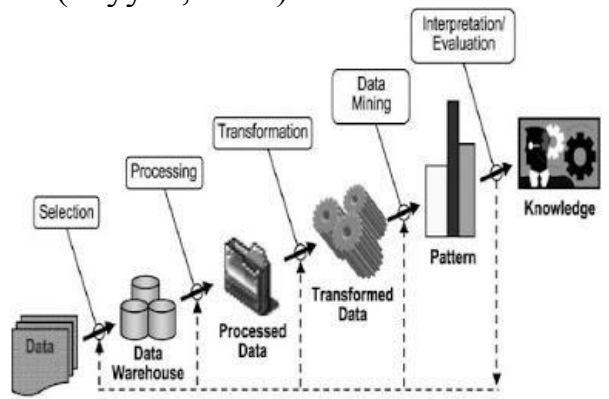

Gambar 1 : Tahapan data mining

1. Data selection

Pemilihan (seleksi) data dari sekumpulan data operasional perlu dilakukan sebelum tahap penggalian informasi dalam KDD dimulai.

2. Pre-processing/cleaning

Proses cleaning mencakup antara lain membuang duplikasi data, memeriksa data yang inkonsisten, dan memperbaiki kesalahan pada data.

3. Transformation

Coding adalah proses transformasi pada data yang telah dipilih, sehingga data tersebut sesuai untuk proses data mining.

4. Data mining

Data mining adalah proses mencari pola atau informasi menarik dalam data terpilih dengan menggunakan teknik atau metode tertentu.

\section{Interpretation / evalution}

Pola informasi yang dihasilkan dari proses data mining perlu ditampilkan dalam bentuk yang mudah dimengerti oleh pihak yang berkepentingan. Tahap ini merupakan bagian dari proses KDD yang disebut interpretation.

\subsection{Klasifikasi}

Klasifikasi adalah sebuah proses untuk mencari model atau fungsi yang menjelaskan dan membedakan kelas atau konsep dari data, dengan tujuan untuk menggunakan model dan melakukan prediksi dari kelas suatu objek dimana tidak diketahui label dari kelas tersebut. Model yang ada berasal dari analisis kumpulan data training (objek data dimana kelas label diketahui) (Han dan Kamber, 2006). Algoritma yang dapat digunakan untuk klasifikasi antara lain Naïve Bayes, Adaptive Bayes Network, Decision Tree dan Support Vector Machine.

\subsection{Naïve Bayes Classification}

Klasifikasi naïve bayes adalah pengklasifikasian statistik yang dapat digunakan untuk memprediksi probabilitas keanggotaan suatu class. Klasifikasi ini dikemukakan oleh ilmuan inggris yang bernama Thomas Bayes, yaitu memprediksi peluang dimasa depan berdasarkan pengalaman dimasa sebelumnya sehingga dikenal sebagai Teorema Bayes. Klasifikasi naïve bayes terbukti memiliki akurasi dan kecepatan yang tinggi saat diaplikasikan ke dalam database dengan data yang besar (Kusrini dan Luthfi, 2009) Teorema Bayes memiliki bentuk umum sebagai berikut:

Dalam hal ini 
$\mathrm{X}=$ data dengan class yang belum diketahui $\mathrm{H}=$ hipotesis data $\mathrm{X}$ merupakan suatu class spesifik $\mathrm{P}(\mathrm{H} \mid \mathrm{X})=$ probabilitas hipotesis $\mathrm{H}$ berdasarkan kondisi $\mathrm{X}$

\section{PEMBAHASAN DAN HASIL}

\subsection{Pembahasan}

Berikut ini akan membahas penerapan metode nä̈ve bayes untuk mengklasifikasi pengajuan pinjaman. Metode ini digunakan untuk menghitung perbandingan probabilitas dari masing-masing atribut pada data training yaitu data pengajuan yang sebelumnya sudah diklasifikasi. Proses klasifikasi secara keseluruhan digambarkan pada flowchart dibawah ini.

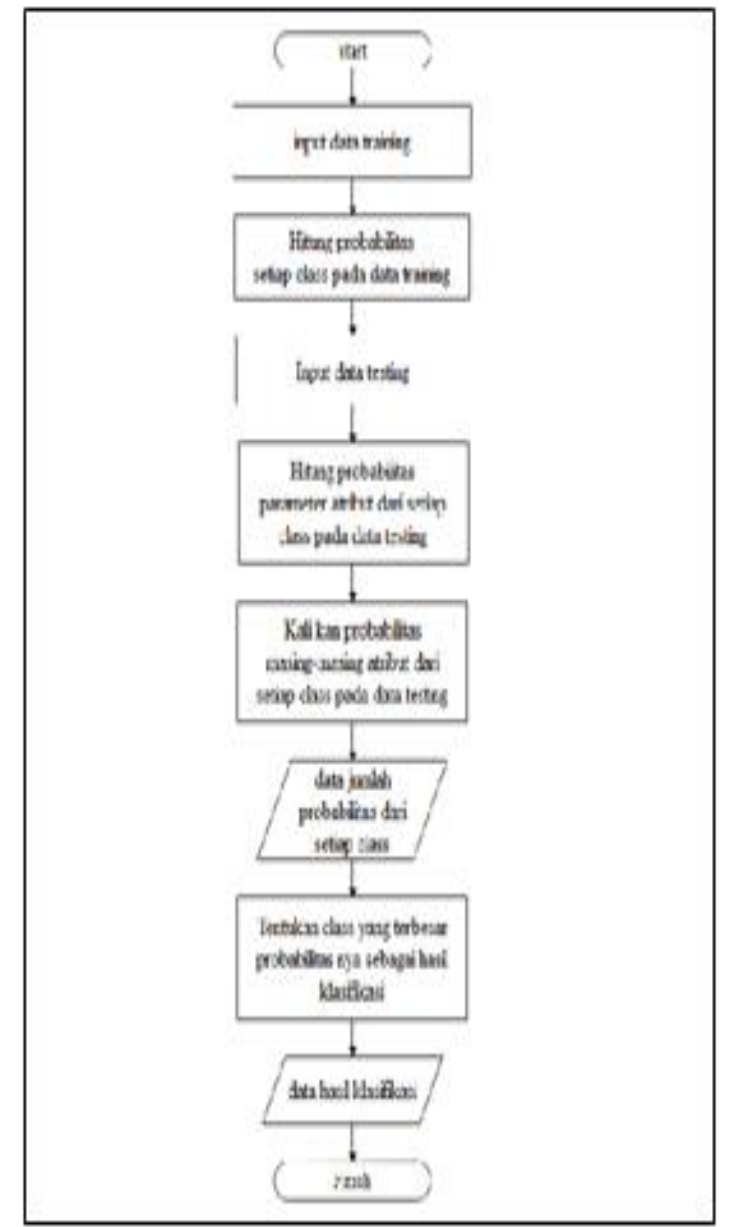

Gambar 2. Flowchart Implementasi Algoritma Naïve bayes

$\mathrm{P}(\mathrm{H}) \quad=$ probabilitas hipotesis $\mathrm{H}$
$\mathrm{P}(\mathrm{X} \mid \mathrm{H})=$ probabilitas $\mathrm{X}$ berdasarkan kondisi pada hipotesis $\mathrm{H}$

$\mathrm{P}(\mathrm{X})=$ probabilitas dari $\mathrm{X}$

Pada Tabel 1 berikut ini dapat dilihat data atribut dan parameter yang digunakan dalam perhitungan naïve bayes.

Tabel 1: Atribut dan parameter perhitungan

\begin{tabular}{|c|c|c|}
\hline Atribut & Parameter & Variabel \\
\hline $\begin{array}{l}\text { Kategori } \\
\text { Pinjaman }\end{array}$ & $\begin{array}{l}\text { Biaya Pendidikan } \\
\text { Biaya pengobatan } \\
\text { Bantu orangtua } \\
\text { Biaya pernikahan } \\
\text { Biaya kontrakan }\end{array}$ & X1 \\
\hline Jabatan & $\begin{array}{l}\text { Staff } \\
\text { Supervisor } \\
\text { Manager } \\
\text { General Manager }\end{array}$ & $\mathrm{X} 2$ \\
\hline $\begin{array}{l}\text { Masa } \\
\text { kerja }\end{array}$ & $\begin{array}{l}1-2 \text { tahun } \\
3-5 \text { tahun } \\
>5 \text { tahun }\end{array}$ & X3 \\
\hline $\begin{array}{l}\text { Range } \\
\text { pinjaman }\end{array}$ & $\begin{array}{l}<2,000,000 \\
2,000,000-2,999,999 \\
3,000,000-4,999,999 \\
5,000,000-6,999,999 \\
7,000,000-9,999,999 \\
10,000,000-12,999,999 \\
13,000,000-14,999,999 \\
15,000,000-19,999,999 \\
20,000,000-29,999,999 \\
>=30,000,000\end{array}$ & $\mathrm{X} 4$ \\
\hline $\begin{array}{l}\text { Jumlah } \\
\text { angsuran }\end{array}$ & $\begin{array}{l}10 \text { bulan } \\
20 \text { bulan } \\
30 \text { bulan }\end{array}$ & $\mathrm{X} 5$ \\
\hline
\end{tabular}

\subsection{Perhitungan Naïve Bayes}

Algoritma Nä̈ve Bayes digunakan untuk menghitung perbandingan probabilitas dari masing-masing atribut pada data training. berikut merupakan perhitungan menggunakan algoritma Nä̈ve Bayes dengan mengambil 10 data sebagai data training dan 1 data sebagai data testing. Data training yang dipergunakan adalah data pengajuan pinjaman yang telah dilakukan klasifikasi sebelum nya. Dalam implementasi ini penulis menggunakan 7 data pengajuan pinjaman yang disetujui dan 3 data pengajuan pinjaman yang di revisi. 
Tabel 2 : Data training

\begin{tabular}{|c|c|c|c|c|c|c|}
\hline Nama & $\begin{array}{c}\text { Kategori } \\
\text { pinjaman }\end{array}$ & Jabatan & $\begin{array}{c}\text { Masa } \\
\text { kerja }\end{array}$ & Range Pinjaman & $\begin{array}{c}\text { Jumlah } \\
\text { Angsur }\end{array}$ & class \\
\hline Niki & Biaya kontrak & Staff & $3-5 \mathrm{thn}$ & $7 \mathrm{jt}-9,9 \mathrm{jt}$ & $10 \mathrm{bln}$ & revisi \\
\hline Nandi & Biaya Pengobatan & Spv & $>5 \mathrm{Thn}$ & $10 \mathrm{jt}-12,9 \mathrm{jt}$ & $20 \mathrm{bln}$ & disetujui \\
\hline Azis & Biaya kontrak & GM & $>5 \mathrm{Thn}$ & $20 \mathrm{jt}-29,9 \mathrm{jt}$ & $30 \mathrm{bln}$ & disetujui \\
\hline Yuni & Biaya Pendidikan & Mngr. & $>5 \mathrm{Thn}$ & $3 \mathrm{jt}-4,9 \mathrm{jt}$ & $10 \mathrm{bln}$ & disetujui \\
\hline Dian & Biaya pendidikan & Staff & $3-5 \mathrm{th}$ & $5 \mathrm{jt}-6,9 \mathrm{jt}$ & $10 \mathrm{bln}$ & disetujui \\
\hline Nono & Biaya pengobatan & Staff & $3-5 \mathrm{Th}$ & $10 \mathrm{jt}-12,9 \mathrm{jt}$ & $20 \mathrm{bln}$ & direvisi \\
\hline Asep & Biaya pengobatan & Staff & $>5 \mathrm{thn}$ & $10 \mathrm{jt}-12,99 \mathrm{jt}$ & $20 \mathrm{bln}$ & direvisi \\
\hline Asrul & Biaya kontrak & Mngr. & $>5 \mathrm{thn}$ & $5 \mathrm{jt}-6,9 \mathrm{jt}$ & $10 \mathrm{bln}$ & disetujui \\
\hline Sadah & Biaya pendidikan & Staff & $3-5 \mathrm{Thn}$ & $3 \mathrm{jt}-4,9 \mathrm{jt}$ & $10 \mathrm{bln}$ & disetujui \\
\hline Rindy & Biaya pendidikan & Staff & $1-2 \mathrm{thn}$ & $3 \mathrm{jt}-4,9 \mathrm{jt}$ & $10 \mathrm{bln}$ & revisi \\
\hline Inu & Biaya pendidikan & Staff & $1-2 \mathrm{Thn}$ & $<2 \mathrm{jt}$ & $10 \mathrm{bln}$ & disetujui \\
\hline
\end{tabular}

Untuk mencari data yang belum diketahui kelasnya, dapat dilihat pada Tabel 2 di bawah ini

Tabel 2 : Data Pengajuan yang belum terklasifikasi

\begin{tabular}{|c|c|c|c|c|c|c|}
\hline Nama & Kategori pinjaman & Jabatan & Masa kerja & Range pinjaman & Jumlah Angsur & class \\
\hline Dede & Biaya pengobatan & Staff & $>5$ thn & $10 \mathrm{jt}-12,9 \mathrm{jt}$ & $10 \mathrm{bln}$ & $?$ \\
\hline
\end{tabular}

Mencari nilai probabilitas atribut pada setiap kelas

Class disetujui

$\mathrm{P}($ Kategori pinjaman $=$ Biaya pengobatan $\mid \mathrm{Y}$

$=$ disetujui $)=1 / 6=0,16$

$\mathrm{P}($ Jabatan $=\operatorname{staff} \mid \mathrm{Y}=$ disetujui $)=3 / 6=0,5 \mathrm{P}$

(Masa kerja $=>5$ thn $\mid \mathrm{Y}=$ disetujui) $=4 / 6$

$=0,67$

$\mathrm{P}($ Range pinjaman $=10,000,000-12,999,999$

$\mathrm{Y}=$ disetujui) $=1 / 6=0,16$

$\mathrm{P}($ Jumlah angsuran $=10 \mathrm{bln} \mid \mathrm{Y}=$ disetujui $)=$ $4 / 6=0,67$

Class direvisi

$\mathrm{P}($ Kategori pinjaman $=$ Biaya pengobatan $\mid \mathrm{Y}$

$=$ direvisi $)=2 / 4=0,5$

$\mathrm{P}($ Jabatan $=\operatorname{staff} \mid \mathrm{Y}=$ direvisi $)=4 / 4=1$

$\mathrm{P}($ Masa kerja $=>5$ thn $\mid \mathrm{Y}=$ direvisi $)=1 / 4=$ 0,25
$\mathrm{P}($ Range pinjaman $=10,000,000-12,999,999$

$\mid \mathrm{Y}=$ direvisi $)=2 / 4=0,5$

$\mathrm{P}($ Jumlah angsuran $=10 \mathrm{bln} \mid \mathrm{Y}=$ direvisi $)=$ $2 / 4=0,5$

Jumlah probabilitas pada tiap class Maka $\mathrm{P}$

( $\mathrm{Y}=$ disetujui $)=$

$0,16^{*} 0,5^{*} 0,67 * 0,16^{*} 0,67=0.0057$

Maka $\mathrm{P}(\mathrm{Y}=\operatorname{direvisi})=$

$0,5 * 1 * 0,25 * 0,5 * 0,5=0.03125$

Kesimpulan hasil yang diperoleh dari perhitungan menunjukan bahwa masukan pada tabel 5.3. menghasilkan ( $\mathrm{P}=$ direvisi) dengan hasil probabilitas tertinggi

\subsection{Hasil Penelitian}

Hasil dari penelitian ini adalah aplikasi berbasis web yang dapat mengklasifikasi pengajuan pinjaman menggunakan metode naïve bayes classifier. 


\subsubsection{Tampilan Login}

Tampilan awal saat pengguna mengakses sistem, adalah tampilan login yang berfungsi sebagai pintu masuk dan proses identifikasi hak akses pengguna setelah masuk kedalam sistem. Tampilan login adalah sebagai berikut.

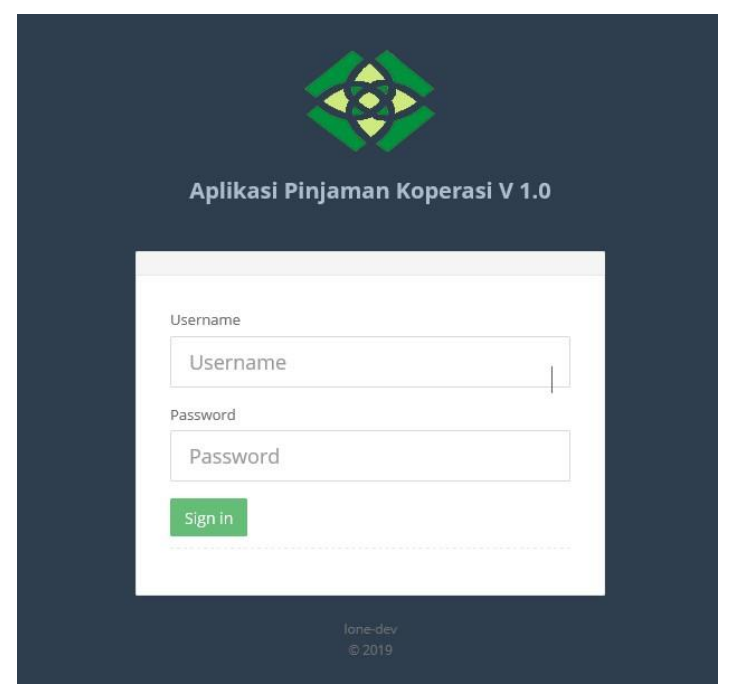

Gambar 3 : Tampilan Login Aplikasi

\subsubsection{Tampilan Dashboard}

1. Dashboard administrator (IT)

Menu yang tampil pada dashboard administrator adalah menu master dengan sub menu user untuk mengelola data user, sub menu atribut untuk mengelola data atribut dan sub menu parameter untuk mengelola data parameter.

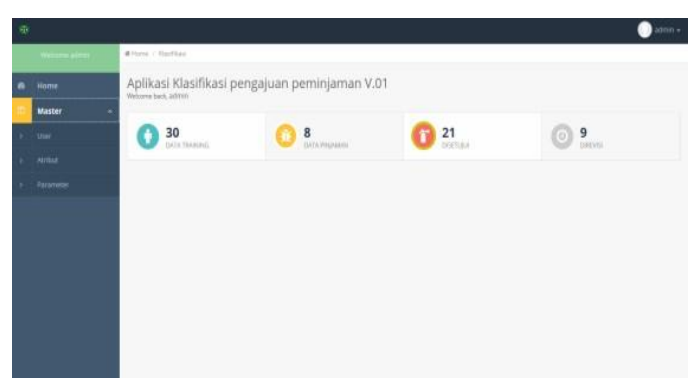

Gambar 4 : Dashboard Administrator

2. Dashboard pengurus koperasi

Menu yang tampil pada dashboard pengurus koperasi adalah menu transaksi dengan sub menu data training untuk mengelola data training, sub menu data pinjaman untuk mengelola data pinjaman dan sub menu hasil klasifikasi untuk melihat hasil perhitungan klasifikasi, menu laporan dan menu bantuan.

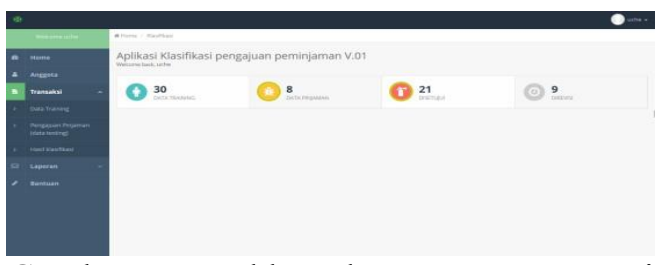

Gambar 5 : Dashboard Pengurus Koperasi

3. Dashboard manajemen koperasi

Menu yang tampil pada dashboard manajemen adalah menu approval untuk ngeapprove hasil klasifikasi pinjaman, menu laporan dan menu bantuan

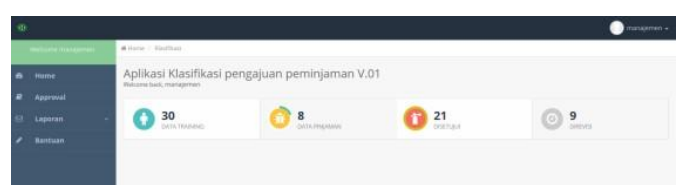

\section{Gambar 6 : Dashboard Manajemen Koperasi}

\subsubsection{Tampilan Kelola Data Master}

Pada menu data master terdapat tiga sub menu yaitu data user, data atribut dan data parameter, submenu data user berfungsi untuk mengelola data pengguna dan hak akses pengguna. Tampilan menu data user adalah sebagai berikut.

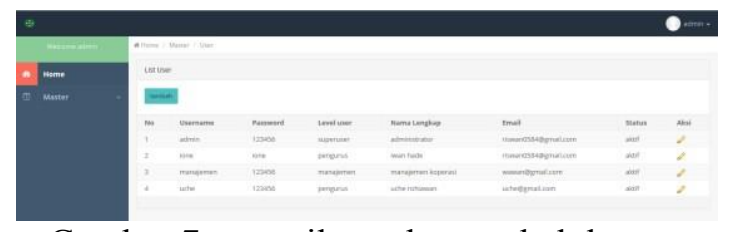

Gambar 7 : tampilan submenu kelola user

Selain menu user terdapat submenu atribut yang berfungsi untuk mengelola data atribut untuk perhitungan probabilitas dalam menentukan kelayakan pinjaman, dibawah ini merupakan tampilan menu atribut.

Submenu terakhir pada data master yaitu data parameter yang berisi parameterparameter yang terdapat pada setiap atribut yang berfungsi untuk perhitungan probabilitas dari setiap atribut, berikut ini merupakan tampilan menu parameter.

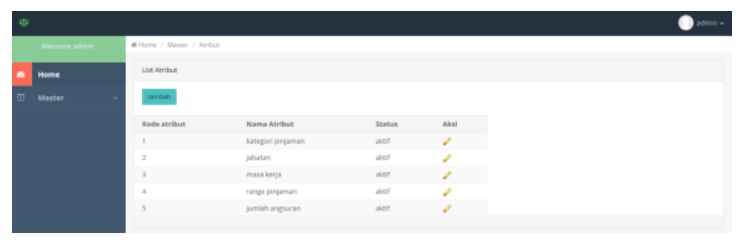

Gambar 8 : tampilan submenu kelola atribut 


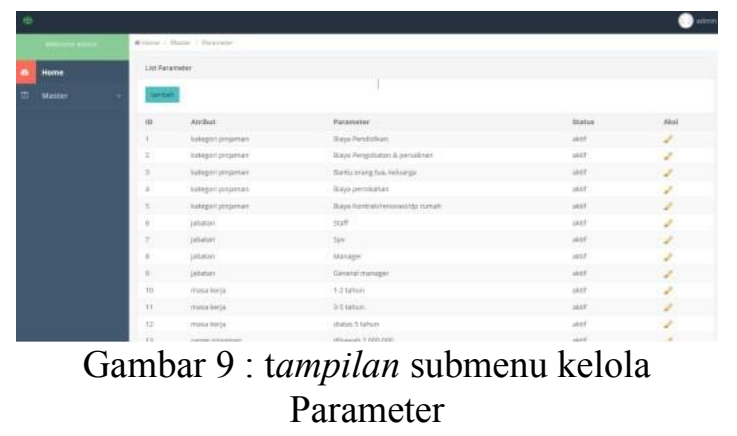

\subsubsection{Tampilan Menu Transaksi}

Pada menu transaksi ini terdapat tiga submenu yaitu data training, data pengajuan pinjaman dan data hasil klasifikasi, submenu data training berfungsi untuk mengelola data training, tampilan submenu data training adalah sebagai berikut.

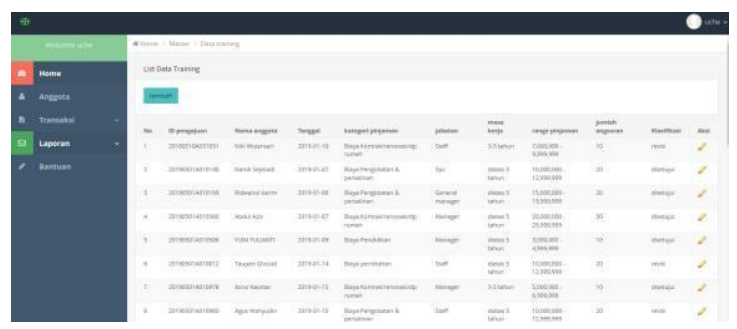

Gambar 10 : tampilan submenu kelola data training

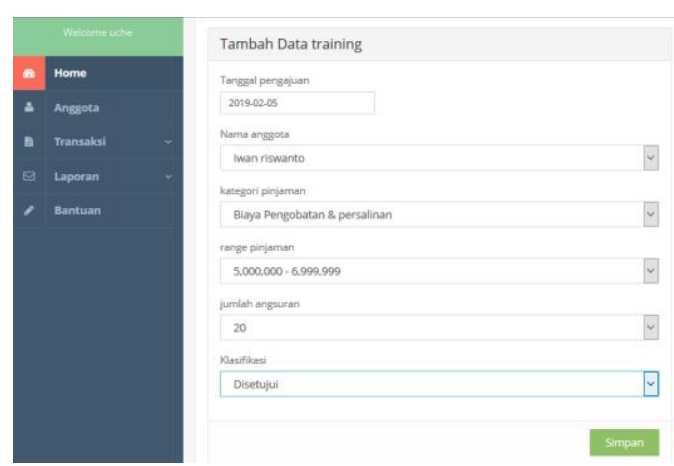

Gambar 11 : tampilan tambah data training

Selain submenu data training terdapat submenu data pengajuan yang berfungsi untuk mengelola data pengajuan pinjaman yang nanti nya akan diproses klasifikasi nya menggunakan metode naïve bayes, dibawah ini merupakan tampilan menu data pengajuan.

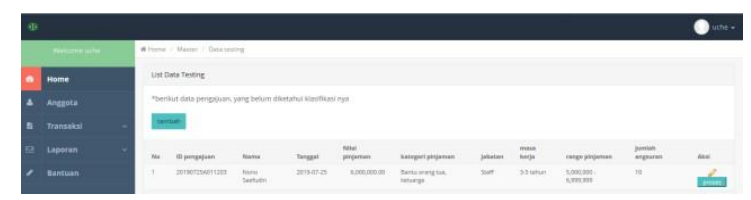

Gambar 12 : tampilan submenu kelola data pengajuan pinjaman
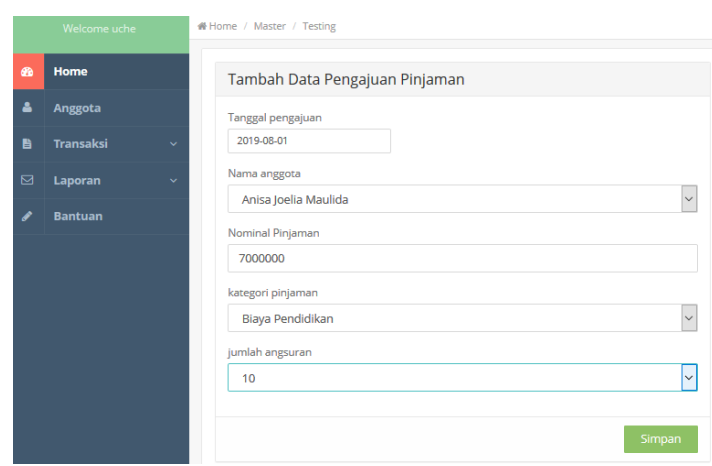

Gambar 13 : tampilan submenu kelola data pengajuan pinjaman

Submenu terakhir pada data transaksi yaitu hasil klasifikasi yang berisi hasil dari proses klasifikasi pengajuan pinjaman, berikut ini merupakan tampilan hasil klasifikasi.

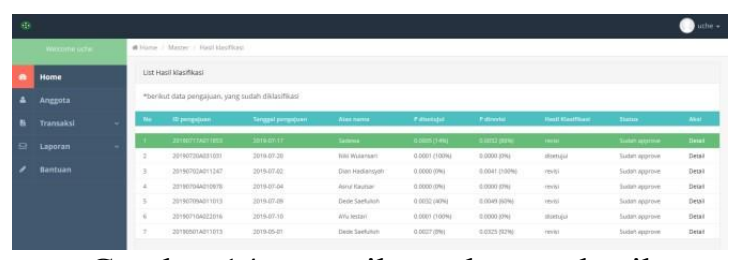

Gambar 14 : tampilan submenu hasil klasifikasi pengajuan pinjaman

Hasil klasifikasi detail nya ditunjukan pada gambar 15 berikut

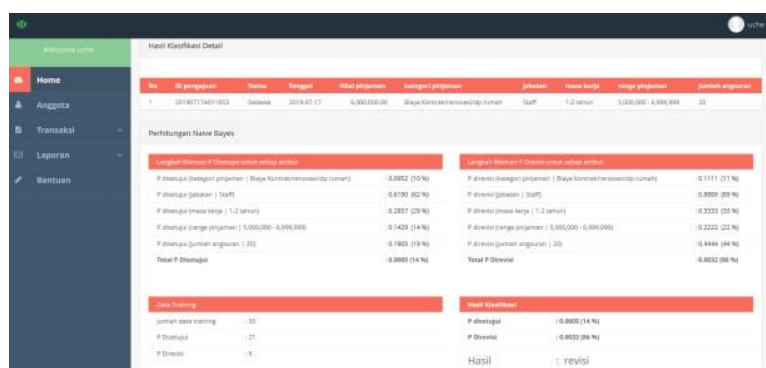

Gambar 15 : tampilan submenu hasil klasifikasi detail

\section{DAFTAR PUSTAKA}

[1] Kurniawan D.A,2018, Aplikasi Prediksi Kelayakan Calon Anggota Kredit Menggunakan Algoritma Naïve Bayes, Solo

[2] Kusrini, Luthfi taufiq emha,2009, Algoritma Data Mining, Andi:Bandung.

[3] Riyanto, 2011, Membuat Sendiri Aplikasi PHP \& Mysql menggunakan Codeigniter,Andi:Bandung.

[4] Al Khautsar, Puspitasari, Mustika, 2018, Algoritma Naïve Bayes Untuk Memprediksi Kredit Macet Pada Koperasi Simpan Pinjam, Jurnal BSI, Jakarta. 